\title{
Nomadic organization structure and mimetic isomorphism in tourism establishments: Focus on small enterprises in Fethiye $^{1}$
}

\author{
Pelin Arsezen Otamış ${ }^{2}$
}

\begin{abstract}
This study has a descriptive nature. The main purpose of this study is to examine the prevalence of nomadic organizations and mimetic isomorphism behaviors in tourism sector. In this study, data which was acquired from the interviews made with the owners of small enterprises was analyzed. At the end of the analysis, it was found out that there was a potential of nomadic organization in simple structure tourism establishments and they used mimicking other establishments as an alternative for the strategy.
\end{abstract}

Keywords: Nomadic organization; isomorphism; Tourism; Fethiye.

\section{Introduction}

This study builds on Kirca's (2007) research. In his master's thesis, he studied nomadic organization and mimetic isomorphism at the small business. It is a premise of the study. This study bears similarities with his work. However, this study was conducted in the tourism sector, which is a different and very dynamic sector.

Organizations are in pursuit of surviving in multi-variable and very dynamic environments (Özen\&Özen, 2011). The obligation of being flexible to these rapidly changing conditions and reacting rapidly creates the condition of evaluating the environment very well (Hannan\&Freeman, 1977). Small enterprises try to acquire long term sustainability with their flexibilities (Mead\&Liedholm, 1998). Tourism is one of the sectors affected easily by both competition and environmental dynamics (Hunter, 1997). Small enterprises in tourism sector try to overcome the uncertainty with their distinctive features and skills (Lew, Hall \& Williams, 2004). The said factors provide a suitable basis for nomadic organizations and mimetic isomorphism.

In this context, this study seeks answers for the following two questions:

- Is nomadic organization structure common in small enterprises in tourism sector?

- Do the small enterprises in tourism sector show mimetic isomorphism behavior?

The study was designed to find answers for these questions. The acquired findings support the fact that enterprises show nomadic and mimetic isomorphism behaviors.

\section{Nomadic Organizations}

Deleuze, Guattari (1988) and Braidotti (1994) used nomadic organization concept for the first time. According to them, nomadic organizations are the firms which are permanently on the move, are in touch with other organizations and possess the possibility to change their

\footnotetext{
1 This paper has been granted by the Mugla Sitki Kocman University Research Projects Coordination Office. Project Grant Number 15/216 and title “Effect of Micro And Small Tourism Businesses' Owner-Managers' Management Practices On Business Performance: Case Of Fethiye"

2 Assist. Prof. Dr., Muğla Sitkı Koçman University, Faculty of Tourism, Department of F\&B Management, pelinarsezen@mu.edu.tr
} 
Arsezen Otamış, P. (2016). Nomadic organization structure and mimetic isomorphism in tourism establishments: Focus on small enterprises in Fethiye. Journal of Human Sciences, 13(3), 6011-6019. doi:10.14687/jhs.v13i3.4360

organizational areas frequently (transmitting Kırca, 2007). Nomadic organizations are organizational structures at the same time. Nomadic organizations naturally tend to move in order to find new sources or trade circle that can bring profit in the areas where uncertainty is pretty high (Sthyre, 2001).

Nomadic organizations are a form of entrepreneur organizations; because nomadic organizations follow also other sectors that are evaluated as bringing profit with the strategy of "permanently being aware of their environment" apart from their own environment. And as soon as this kind of sector is detected within the interest area, they enter into this sector and get involved in the movement of attendance to the mob by mimicking generally accepted behaviors and moves there (Kirca, 2007).

Styhre (2001) argues that nomadic organization structure means acquisition, a flexible and transitive organization structure in all cases and it appears in order to continue sustainability and deal with trade circles in which innovations that are introduced as creative for the organization are destroyed by the environment easily.

Behind the opportunist attitudes of nomadic organizations, there may be mimetic isomorphism mechanisms. Within the high uncertainty environment in Turkey, it is observed that number of organizations moving fast in the phase of establishment in various sectors is increasing by mimicking each other and they are reaching large organizational populations (Sargut, 2009). In this regard, it can be thought that high uncertainty and being nomadic organization in a dynamic environment can create an advantage.

Nomadic organizations are the enterprises whose establishment processes are fast and which possess the ability to mimic each other by their living and moving philosophy. By this means, they start their circle of work rapidly and then look for another sector to leak in when the market achieves satisfaction. Due to the fact that nomadic organizations generally maintain their lives with the strategy of "I will do what other organizations are doing, I will move in the same direction", the only concern for them is the opportunities appearing in the environment as specified in the second phase. Nomadic organizations are mostly interested in profit issue. Legitimacy and threats to occur in the environment are probably not very important for them; since they will carry out their work for a very short time (Kirca, 2007).

Areas which are numerous in tourism destinations such as souvenir shop, market, grocery, which allow for simple-structured organizations and whose access to the sector is relatively easy are attractive for opportunist nomadic enterprises. Tourism destinations are sort of attraction areas for nomadic enterprises.

\section{Mimetic Isomorphism}

According to institutional theory, organizations are formed through various regulative systems within their institutional areas. The main thesis of institutional theory is that structure and processes of organizations are formed as a result of their adaptability to the environment in which they are active (Kirca, 2007). Institutional environment is an environment which is formed aside from and above the organizations along with modernization process and which includes rationalized structures, rules, norms, believes and legends. In order to maintain their lives, organizations should not only become efficient technically, but also legitimate themselves by adapting to the institutions in this environment (Sargut, 2009).

According to institutional theory, isomorphism is available as necessitated by the society and environment in which organizations are active. For this reason, organizations become isomorphic. Institutional theory asserts that organizations which are within the same institutional area will resemble each other in time through regulative, normative and cognitive mechanisms. This resemblance situation and process is named as isomorphism (DiMaggio and Powell, 1983).

DiMaggio and Powell (1983) established that organizations were affected by three mechanisms in terms of isomorphism: compulsory, regulative and mimetic. Although each of these 
Arsezen Otamış, P. (2016). Nomadic organization structure and mimetic isomorphism in tourism establishments: Focus on small enterprises in Fethiye. Journal of Human Sciences, 13(3), 6011-6019. doi:10.14687/jhs.v13i3.4360

is different mechanism affecting organizations, effect of each mechanism is the same. Yet, they enable the assimilation in organizational practice and form.

In Regulative Isomorphism, determinative pressure is oriented to organizations formally or informally (Marquis, Glynn \& Davis, 2007). For example, prohibition of wood and coal furnaces in places near to beaches has oriented catering enterprises to use electric furnaces. On the other hand, Normative Isomorphism is a form resulting from professionalism. For example, a certain type of clothing related with the held profession (chiefs' wearing chief uniform, waiters' wearing suits in luxury restaurants, etc.) is normative isomorphism.

Mimetic Isomorphism is the most efficient isomorphism mechanism within these three mechanisms. Organizations tend to mimic successful similar organizations carrying out the same business with them (DiMaggio and Powell, 1991:70). Strategies, structures and practices of mimicked organizations by taking them as model are acquired through worker transfers and changing business. Moreover, the tendency to perform works with generally accepted methods is also effective in expanding isomorphism organizations (Özen, 2004). Mimetic isomorphism is understood as the logical expression of organizations' mimicking each other's practices which are to reach limited sources in high uncertainty environment through limited procurement channels (Sargut, 2009).

Visible advantage of mimetic movements is the fact that when it is encountered with problems whose results are unclear, these problems can be overcome with the practices whose costs are pretty low (Cyert and March, 1963). Yet, the used structure was available beforehand and it was used as a solution for a similar problem. The only thing that should be done after this point is firm's putting this solution into operation maybe with small changes in order to solve its own problem.

Sargut (2009) argues that mimetic isomorphism pressure appearing in institutional environment enables entrepreneur organizations whose ability to develop strategies is limited to mimic successful structures easily. Due to the fact that these organizations possess the necessary human and financial resources in a limited level both for uncertainty and strategy formulation, they adopt mimicking the organizations which are thought to be successful as a course of action replacing strategy determination. According to Sargut (2009), because of the fact that mimetic isomorphism tendency within organizational population is high, pioneer entrepreneur organizations are mimicked rapidly and therefore they increase their establishment speed and numbers in organizational population.

The most important factor encouraging mimicking is the state of uncertainty as well as economic reasons in the markets in which organizations try to maintain their trade circles (Han, 1994). If organizational technologies are unrealized (if not being able to be followed), targets are ambiguous and environment creates symbolic ambiguities, organizations assimilate their models to other organizations (Brouthers, O'Donell \& Hadjimarcou, 2005). On the other hand, tourism is a sector which possesses environment dynamics feeding mimetic isomorphism (Haveman, 1993).

For example, one of the enterprises interviewed during the study started to operate a kindergarten in an area where it saw that there were a few kindergartens after operating a boutique in a touristic street in Fethiye. When the number of kindergartens increased in just one year, it decided to sell raw and cooked chicken whose supplier was the enterpriser itself and which was thought to be much more profitable. It explained the reason of the desire to incline for that area was that the enterprise from which it bought chicken made good profit and it made sale in cash. It is remarkable that the enterprise did not have any experience in kindergarten or chicken works and these are totally different from each other as work areas.

\section{Research Method}

In this study, it has been aimed to find out whether small tourism enterprises operating in Fethiye possess nomadic organization feature and whether they adopt mimetic isomorphism. Small tourism enterprises operating in Fethiye constitute the population of the research. Because of 
limited time and budget, 30 small tourism enterprises which are thought to represent the main population accepting to attend the research were taken as sample. It is a descriptive research. Primary data used in the research was collected from the owners of small enterprises. Data collection tool is a semi-structured interview form designed by Kirca (2007), updated and amended by the researcher. It was benefitted from SPSS packet program in data analysis; frequency and percentage method was used.

\section{Findings}

Findings acquired as a result of interviews made with the owners of enterprises are summarized in the following graphics.

In Figure 1, there are types of enterprises with whom interviews were made and enterprises' ages.

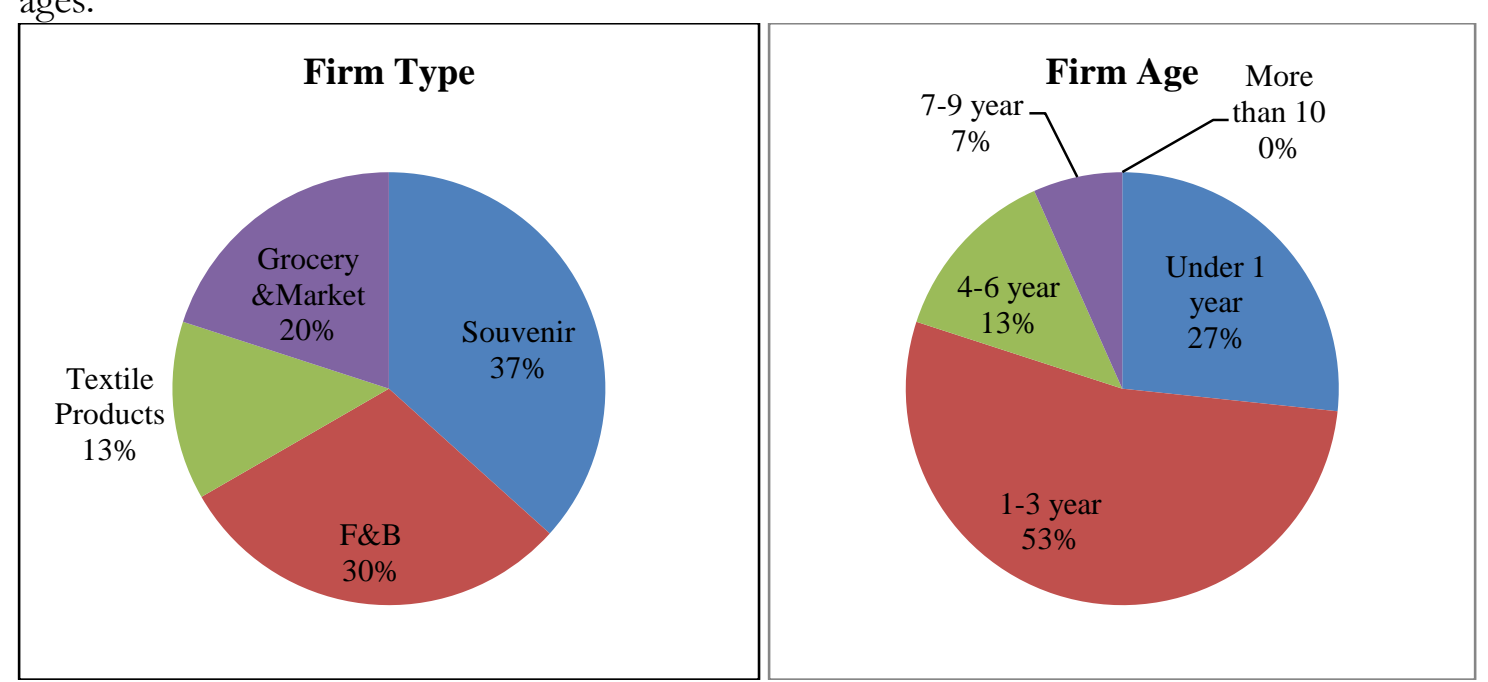

Figure 1. Firm Type \& Age

As it can be seen in Figure 1,37\% of the enterprises attending the research sell souvenir, $30 \%$ of them sell F\&B, $20 \%$ of them sell market/grocery/kiosk and $13 \%$ of them sell textile products. A great majority of the enterprises are between 1 and 3 ages.

Figure 2 shows for how many hours are the enterprises open in a day and how many employees do they have.

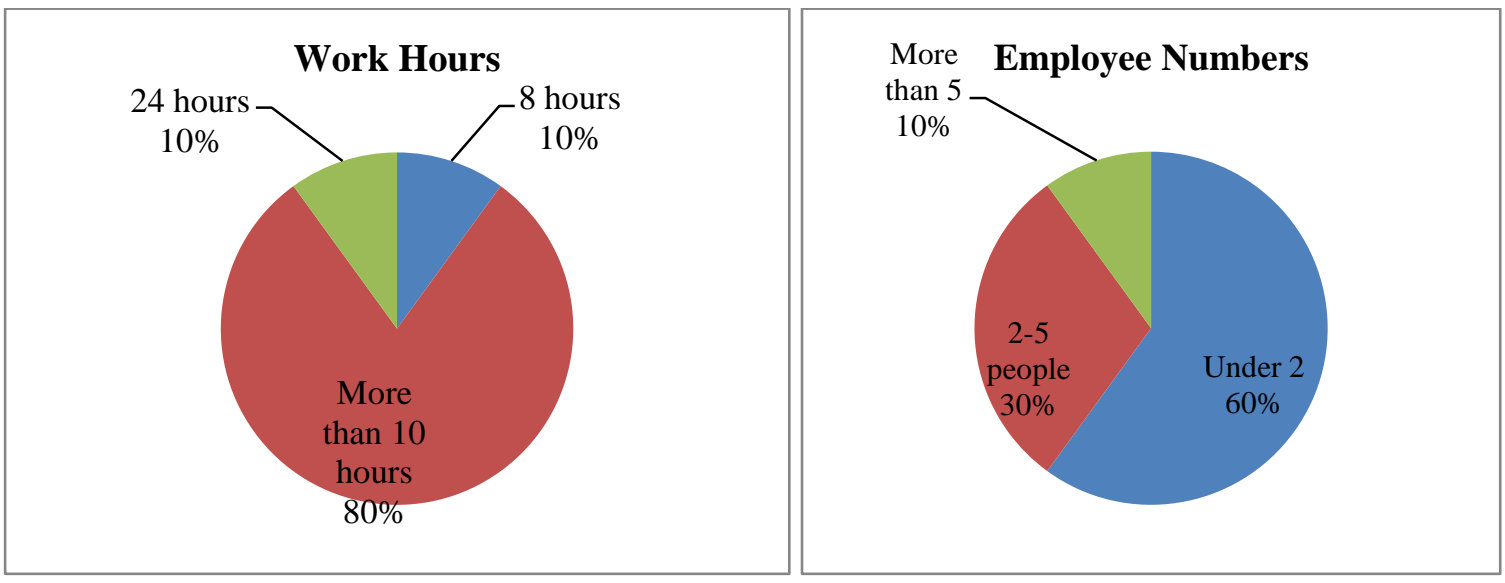

Figure 2. Work Hours\& Employee Numbers 
According to Figure 2, most of the enterprises are open for more than 10 hours a day. Number of employees in the enterprises varies between 2 and 5. This finding confirms that the enterprises are simple-structured.

Figure 3 summarizes the reasons of enterprise owners' preferring simple structure and making amendments.

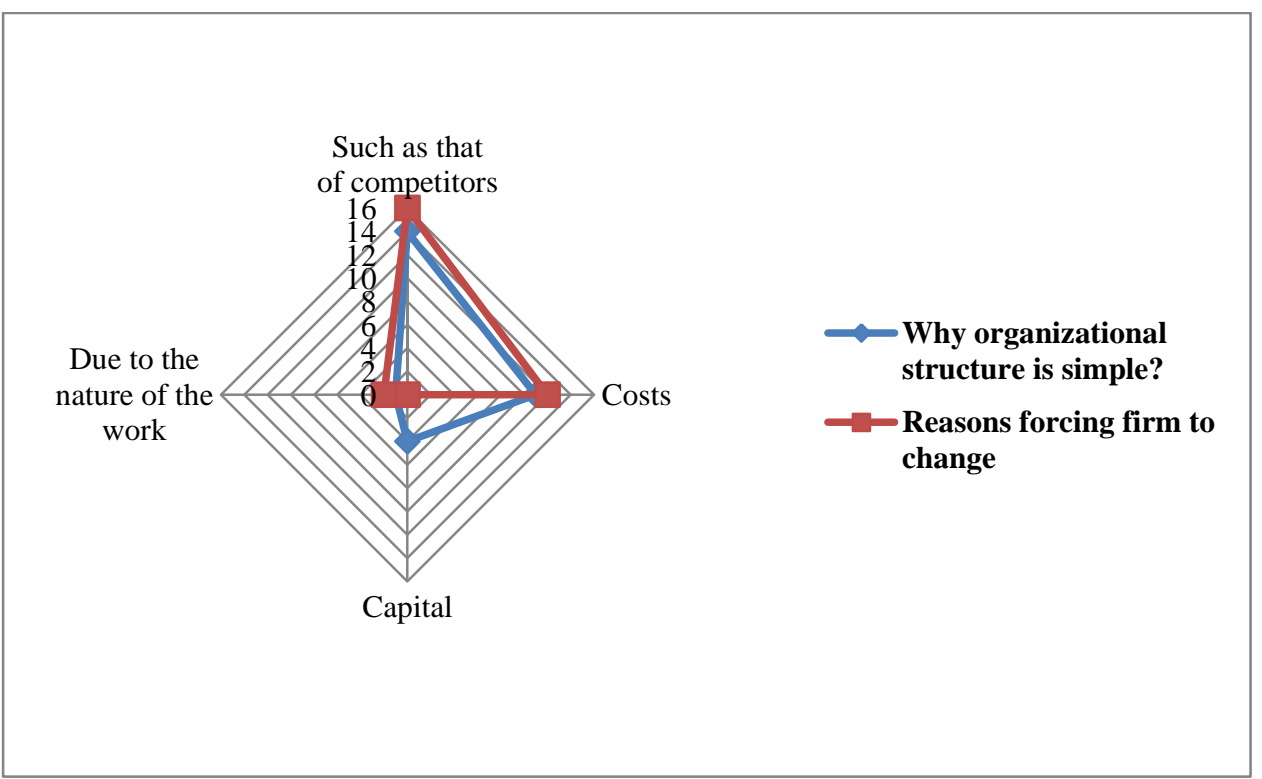

Figure 3. Simple Structure \& Change Reasons

According to Figure 3, the reasons of preferring a simple organization structure are rivals' being simple-structured, rivals' undergoing changes and the costs.

Figure 4 shows the most amended issues and second most amended issues.

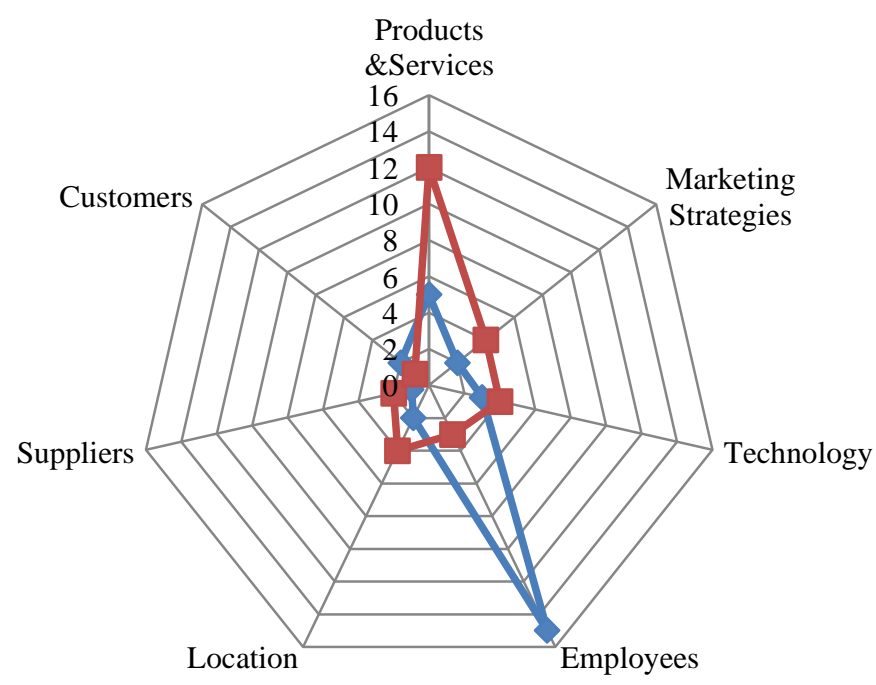

$\sim$ Most issues with change

- Secondary issues with change

Figure 4. Issues With Change 
As it can be seen in Figure 4, the most amended issue is employees and the second most amended issue is products.

Figure 5 summarizes the effective factors in selecting the line of work and the sources applied while dealing with uncertainty.

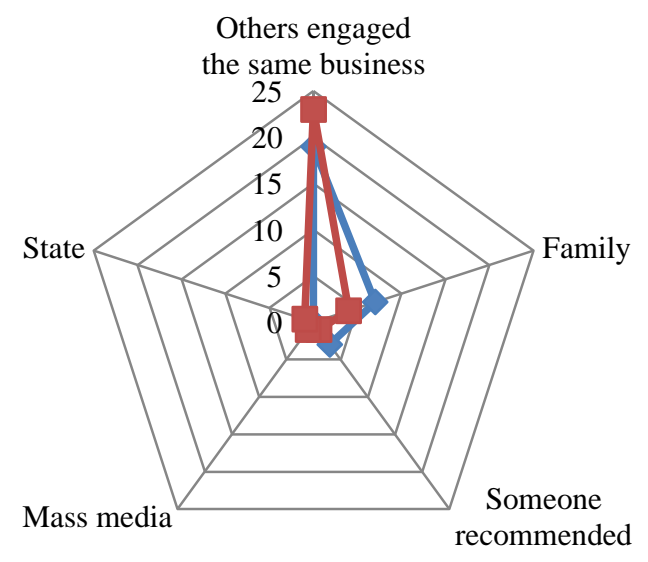

The factors that influence the choice of this business

- Those referenced in coping with uncertainty

\section{Figure 5. Influence \& Uncertainty}

According to Figure 5, entrepreneurs are affected from others carrying out the same work while selecting their line of work. They observe their rivals about what they are doing while dealing with uncertainty.

Figure 6 shows which enterprises are taken as an example most.

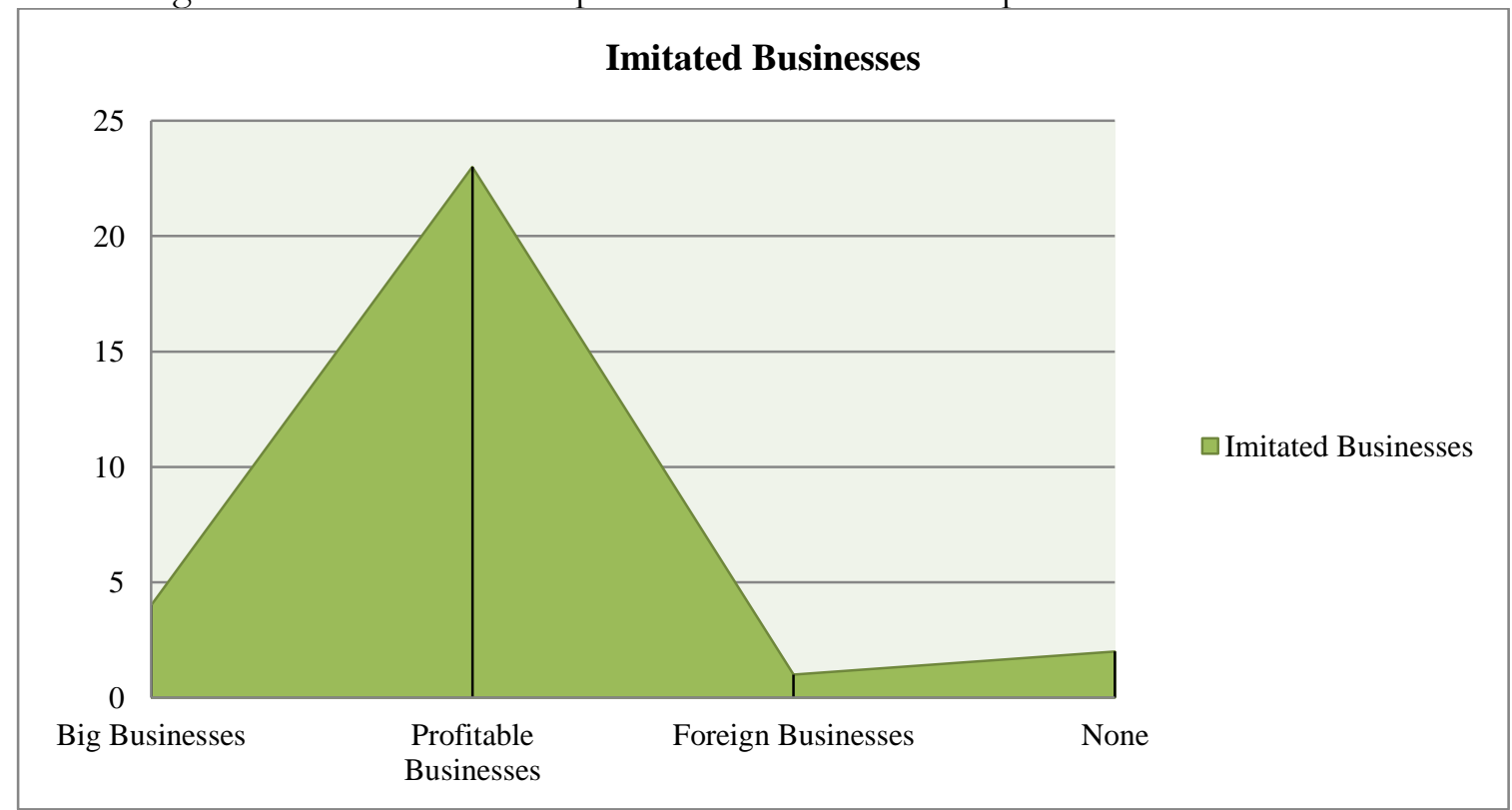

Figure 6. Imitated Business 
According to Figure 6, enterprises mostly take as an example profitable enterprises. This finding is compatible with nomadic enterprise feature.

Figure 7 shows how different are the enterprises from their rivals.

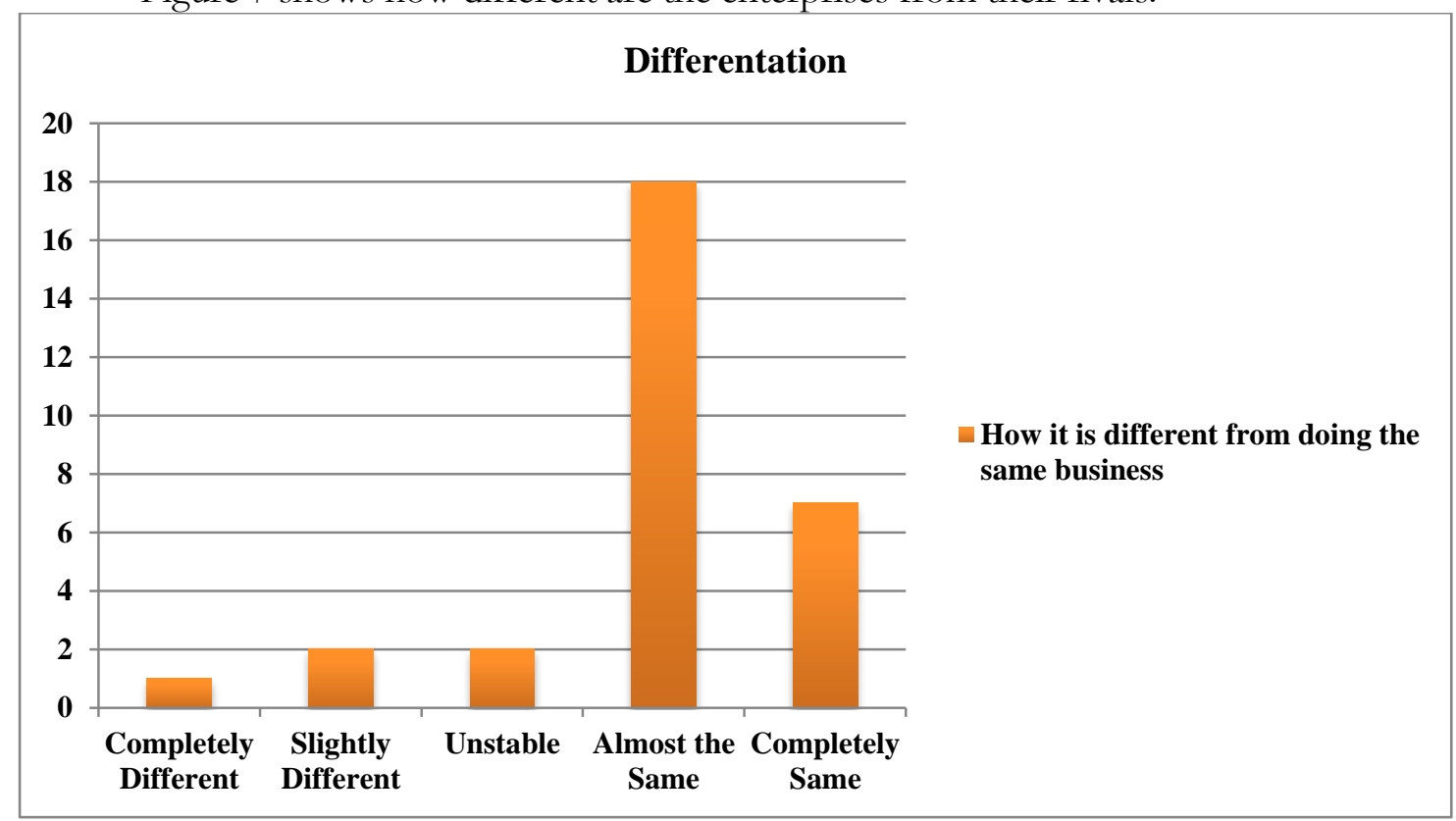

\section{Figure 7. Isomorphism Degree}

According to Figure 7, most of the enterprises resemble to their rivals. Enterprises seem to be isomorphic.

Figure 8 gives enterprises' same aspects with their rivals.

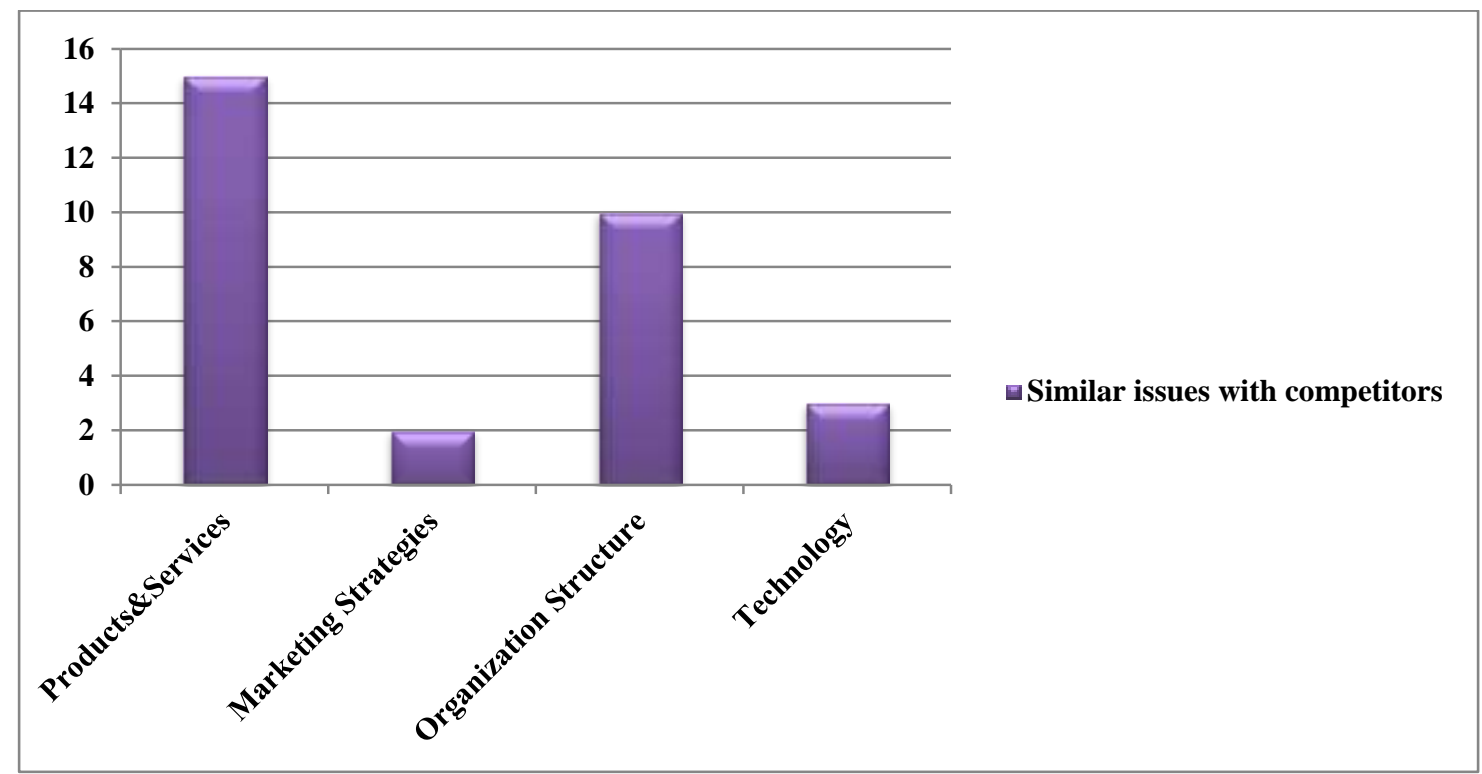

Figure 8. Isomorphism Issues

Enterprises resemble to their rivals in terms of products and organizational structure. This finding indicates an isomorphic structure.

Figure 9 gives the intentions of entrepreneurs to change their work and operate in a more profitable work. 


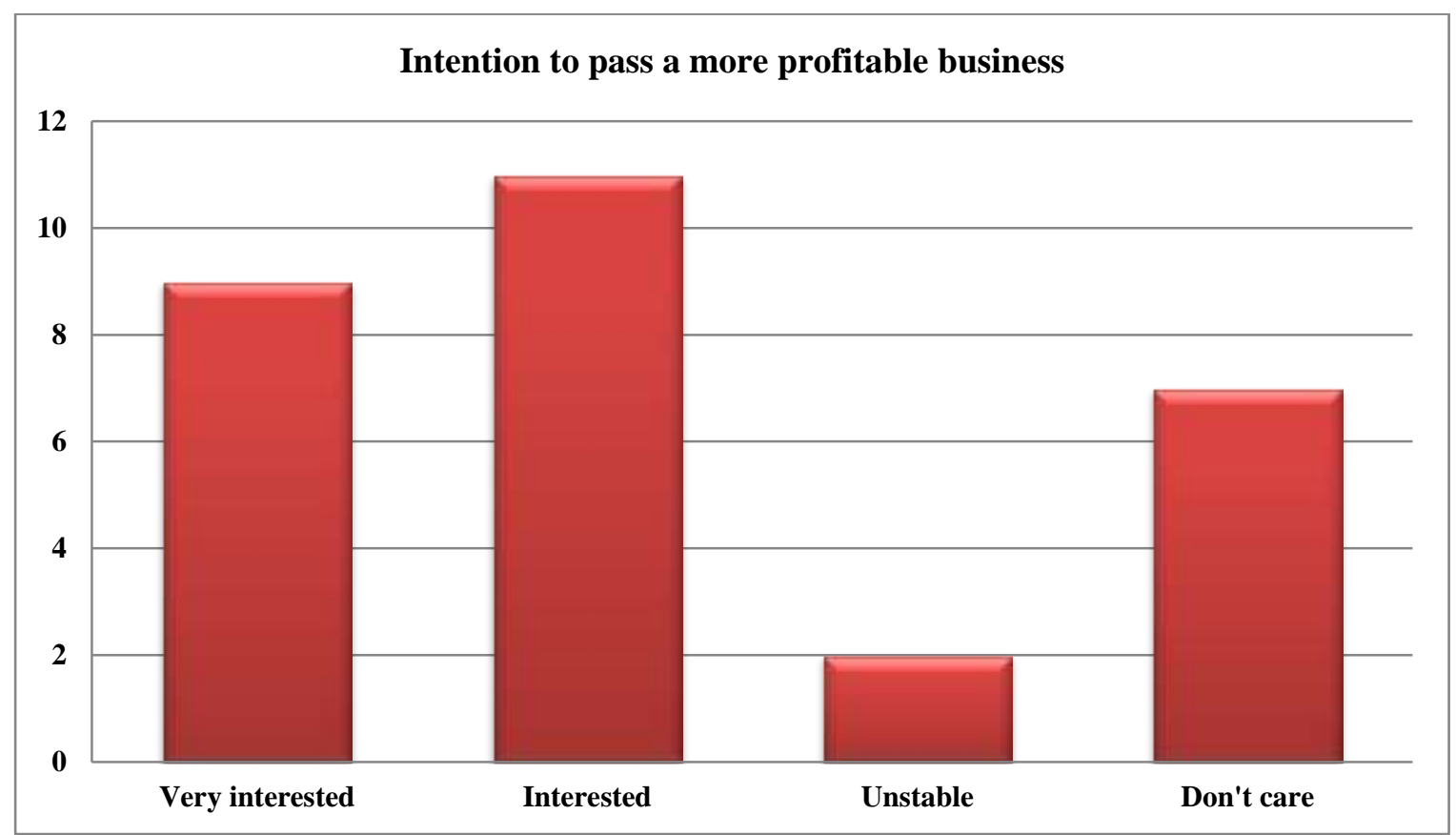

Figure 9. Nomadism Intention

A great majority of enterprises are interested in orienting to more profitable areas. In this context, enterprises possess nomadic organization feature.

Figure 10 summarizes whether enterprises perceive changing work as easy or not.

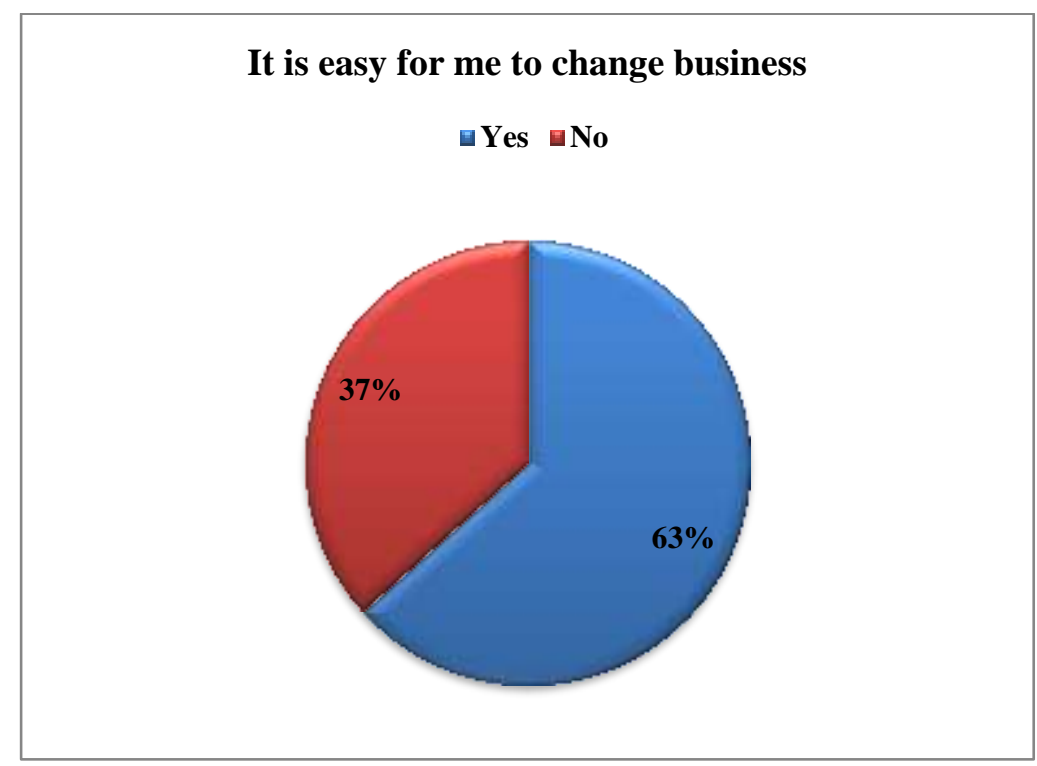

\section{Figure 10. Nomadism}

According to entrepreneurs, it is easy to change the work area their operating right now. This finding supports nomadic organization feature.

According to the findings, most of the small tourism enterprises possess nomadic and mimetic isomorphism features.

\section{Conclusion}

Organizations are not an object independent from their environment. For line of works like tourism which is permanently changing and in which uncertainty is in its top level, organizations are 
Arsezen Otamış, P. (2016). Nomadic organization structure and mimetic isomorphism in tourism establishments: Focus on small enterprises in Fethiye. Journal of Human Sciences, 13(3), 6011-6019. doi:10.14687/jhs.v13i3.4360

subjects that are open to every effect as a result of communication they made with their environment and that are able to react to these effects. In such a case, organizations which desire to survive may prefer mimetic isomorphism as an alternative to the strategy. Or, they may orient to other work area which they find more profitable.

In tourism sector which is completely open to environmental effects, mimetic isomorphism appears in nomadic organizations as an alternative to the strategy in an environment where uncertainty is present. This study aims to find out whether organizational structures of small enterprises in tourism destinations are nomadic organization structure and whether these enterprises adopt mimetic isomorphism behavior or not.

According to the results of the research, entrepreneurs of small tourism enterprises are inclined to change their present work with another line of work which they think that it is more profitable. At the same time, mimetic isomorphism behavior is high in these enterprises.

Limited ability of small tourism entrepreneurs' producing strategy, variable environment and uncertainty, tourism sector's distinctive dynamics seem to feed nomadic organization structure and mimetic isomorphism behaviors.

\section{References}

Brouthers, L. E., O’Donnell E. \& Hadjimarcou, J. (2005). Generic product strategies for emerging market exports into triad nation markets: a mimetic isomorphism approach. Journal of Management Studies 42(1). doi: $10.1111 / j .1467-6486.2005 .00495 . x$

View Article: DOI: http://onlinelibrary.wiley.com/doi/10.1111/j.1467-6486.2005.00495.x/abstract

Cyert, Richard, and James March. 1963. A Behavioral Theory of the Firm. Englewood Cliffs, NJ: PrenticeHall.

DiMaggio, P. J., \& Powell, W. W. (1983). The iron cage revisited: Institutional isomorphism and collective rationality in organizational fields. American Sociological Review, 48, 147-60.

Hannan, M. T., \& Freeman, J. (1977). The population ecology of organizations. American journal of sociology, 929-964. View Article: DOI: https://www2.bc.edu/ jonescq/mb851/Apr9/HannanFreeman_AJS_1977.pdf

Haveman, H. A. (1993). Follow the leader: Mimetic isomorphism and entry into new markets. Administrative science quarterly, 593-627. View Article: DOI: http://www.jstor.org/stable/2393338

Hunter, C. (1997). Sustainable tourism as an adaptive paradigm. Annals of tourism research, 24(4), 850-867. doi:10.1016/S0160-7383(97)00036-4 View Article: DOI: http://www.sciencedirect.com/science/article/pii/S0160738397000364

Han, S. K. (1994). Mimetic isomorphism and its effect on the audit services market. Social Forces, 73(2), 637664. View Article: DOI: https://doi.org/10.1093/sf/73.2.637

Kırca, B. 2007. Göçebe örgütlerde Öykünmeci Eşbiçimlilik: Ankara'da Küçük Ölçekli İşletmeler Üzerine Niteliksel Bir Çalışma

Lew, A. A., Hall, C. M., \& Williams, A. M. (Eds.). (2008). A companion to tourism. John Wiley \& Sons. Marquis, C., Glynn, M. A., \& Davis, G. F. (2007). Community isomorphism and corporate social action. Academy of management review, 32(3), 925-945. doi:10.5465/AMR.2007.25275683 View Article: DOI: http://amr.aom.org/content/32/3/925.full.pdf + html

Mead, D. C., \& Liedholm, C. (1998). The dynamics of micro and small enterprises in developing countries. World development, 26(1), 61-74. doi:10.1016/S0305-750X(97)10010-9

Özen, Ş. (2004). Örgütsel analizde Türkiye kaynaklı kurumsal kuram çalışmaları. Yönetim Araștırmalar Dergisi, 4(2), 89-100.

Özen, H., \& Özen, Ș. (2011). Interactions in and between Strategic Action Fields A Comparative Analysis of Two Environmental Conflicts in Gold-Mining Fields in Turkey. Organization \& Environment, 24(4), 343-363. doi: 10.1177/1086026611426343.

Sargut, A. S. (2009). Türkiye'de işletme yönetimi eğitiminin kurumsal çerçevesi: çeşitlilikten eşbiçimliliğe. Eskiz̧sehir Osmangazi Üniversitesi IIIBF Dergisi, Nisan, 4(1), 51-63.

Styhre, A. (2001). Nomadic Organizations. Tamara: Journal of Critical Postmodern Organization Science. Academic Research Library, 1-12. 